Maurer School of Law: Indiana University

Digital Repository@ Maurer Law

IP Theory

Volume 7 | Issue 2

Article 3

6-2-2018

\title{
Our 19th Century Patent System
}

Gregory Reilly

greilly1@kentlaw.iit.edu

Follow this and additional works at: https://www.repository.law.indiana.edu/ipt

Part of the Intellectual Property Law Commons, and the Science and Technology Law Commons

\section{Recommended Citation}

Reilly, Gregory (2018) "Our 19th Century Patent System," IP Theory. Vol. 7 : Iss. 2 , Article 3.

Available at: https://www.repository.law.indiana.edu/ipt/vol7/iss2/3

This Article is brought to you for free and open access by the Law School Journals at Digital Repository @ Maurer

Law. It has been accepted for inclusion in IP Theory by an authorized editor of Digital Repository @ Maurer Law. For more information, please contact rvaughan@indiana.edu.

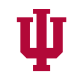

JEROME HALL LAW LIBRARY

INDIANA UNIVERSITY

Maurer School of Law
Bloomington 


\title{
OUR 19TH CENTURY PATENT SYSTEM
}

\author{
Greg Reilly*
}

\section{INTRODUCTION}

The patent system is in flux. Concerns abound about the imperfect fit between traditional patent rights and the Information Age, excessive numbers of patents, overbroad patent rights, poor patent quality, and allegedly exploitative actors, like so-called "patent trolls." In response, courts, commentators, and Congress have proposed, debated, and sometimes adopted a series of reforms and changes to patent rights, patent doctrines, and patent institutions. The America Invents Act of 2011 (AIA) introduced the most significant changes to the patent system since $1952^{2}$ and was even described by one commentator (hyperbolically, as we will see) as "the most significant overhaul to our patent system since the founding fathers first conceived of codifying a grand bargain between society and invention." 3 The Supreme Court's recent renewed interest in patent law ${ }^{4}$ has also resulted in significant changes, including abolishing the long-standing rule that "a patent owner is entitled to permanent injunctive relief once a patent is adjudicated to be both valid and infringed." And scholars have proposed a variety of other significant changes to American patent law. ${ }^{6}$

With change, comes opposition. The changes and proposed changes to patent law have sparked vigorous policy debates about the effects on the patent system's goals of promoting innovation and preserving competition. ${ }^{7}$ But beyond policy disagreement, opponents also are concerned that recent changes and proposed changes reflect a sharp, dramatic break with longstanding, fundamental aspects of the patent system. To them, departing from the historical features

\footnotetext{
* Assistant Professor of Law, Chicago-Kent College of Law. Thanks to Chris Beauchamp, Mark Lemley, and participants at the Intellectual Property Scholars Conference at Cardozo School of Law and the Chicago-Kent faculty workshop for helpful discussions and comments on this and earlier versions of the project.

${ }^{1}$ See Paul Gugliuzza, Patent Litigation Reform: The Courts, Congress, and the Federal Rules of Civil Procedure, 95 B.U. L. REV. 279, 279-280 (2015).

${ }^{2}$ Craig Allen Nard, The Law of Patents 26 (4 ${ }^{\text {th }}$ ed. 2017).

${ }^{3}$ David Kappos, Re-Inventing the U.S. Patent System, DiRECTOR's Forum: David KapPos' PuBliC BLOG (Sept. 16, 2011, 5:45PM), http://www.uspto.gov/blog/director/entry/re_inventing_the_us_patent.

${ }^{4}$ Peter Lee, The Supreme Assimilation of Patent Law, 114 MiCH. L. REV. 1413, 1421-24 (2016).

${ }^{5}$ Andrew Beckerman-Rodau, The Supreme Court Engages in Judicial Activism in Interpreting the Patent Law in eBay, Inc. v. MercExchange, L.L.C., 10 TUL. J. TECH. \& INTELl. PROP. 165, 189 (2007).

${ }^{6}$ See, e.g., Marketa Trimble, Patent Working Requirements: Historical and Comparative Perspectives, 6 UC IRVINE L. REV. 483, 485, 488-489 (2016) (describing renewed interest in a working requirement that would mandate the patentee use its invention within the United States); Maureen A. O'Rourke, Toward a Doctrine of Fair Use in Patent Law, 100 CoLUM. L. REV. 1177, 1179-80 (2000) (proposing a fair use defense to patent law similar to that in copyright); Michael J. Burstein, Rules for Patents, 52 WM. \& MARY L. REV. 1747, 1759-1760 (2011) (proposing development of patent law through ex ante rulemaking in the Patent Office).

${ }^{7}$ See, e.g., Greg Dolin, The Costs of Patent "Reform": The Abuse of the PTO's Administrative Review Programs, Center FOR THE PROTECTION OF InTEllectuAl PROPERTY (December 2014), https://sls.gmu.edu/cpip/wpcontent/uploads/sites/31/2014/04/Dolin-Abuse-of-PTO-Review-Programs.pdf.
} 
of the patent system is inadvisable,${ }^{8}$ illegitimate, ${ }^{9}$ or even unconstitutional. ${ }^{10}$

This Essay provides context necessary to evaluate these concerns. Recent changes and proposed changes seem like a dramatic and sharp break with past practice precisely because the patent system has been remarkably stable since the middle of the 19th century. To many in the patent community, this contention may seem surprising, or even laughable, given widespread recognition of significant adjustments and fluctuations in the patent system over the years. ${ }^{11}$ The patent system certainly undergoes doctrinal variations at the operational level of applying patent law's specific requirements to determine if particular patents are valid and infringed - for example, the specific tests used or defenses available. ${ }^{12}$ There also have been changes in how the patent system is used over time, including the volume of patenting and patent enforcement activity. ${ }^{13}$

But at a foundational or systemic level, the nature of the rights granted, the institutional structure of the patent system, and the basic doctrines of patentability, infringement, and remedies have remained largely constant. It is exactly because the foundational and systemic aspects of the patent system have been so constant that the fluctuations in doctrinal implementation seem so significant. ${ }^{14}$ For example, the proper test for determining whether an invention is too obvious to warrant a patent, much debated in the patent community, would seem relatively minor compared to a reform requiring the Patent Office to decide whether to issue a patent based on a case-by-case determination of whether the innovation benefits of a particular patent outweigh its social costs. Even the question of when inventions are patent ineligible abstract ideas, laws of nature, or natural phenomena-probably the most contested current patent issue-would become much less significant if Congress started debating abolishing patents for some industries, imposing price controls on patented products, setting mandatory licensing terms, or replacing the private right of action for patent infringement with government enforcement.

But long-standing stability in the foundational and systemic characteristics of the patent system does not mean that these characteristics are inevitable, necessary, or mandatory features. To the contrary, in the first few decades of the American patent system, there was significant change, experimentation, and development in the nature of patent rights, the patent system's

\footnotetext{
${ }^{8}$ See, e.g., Dana Rohrabacher, 'Patent Reform' Will Hurt Innovation, National ReVIEW (June 22, 2011, 8:00AM), https://www.nationalreview.com/2011/06/patent-reform-will-hurt-innovation-dana-rohrabacher/ (opposing the switch to a first-to-file system because it would "overturn 200 years of legal precedent" that "for 200 years has protected inventors and fostered an environment of economic growth."); see also, e.g., Maureen K. Ohlhausen, Acting Chairman, Fed. Trade Comm'n, Address at the "Markets, Government, and the Common Good" Conference: Strong Patent Rights, Strong Economy (Oct. 13, 2017), https://www.ftc.gov/system/files/documents/public_statements/1264483/ohlhausen_-_hillsdale_speech_10-1317.pdf (objecting to reforms to restrict patent rights on the basis of "over two hundred year history during which the United States, driven by technological innovation, emerged as the world's leading economy" based on historically "strong intellectual property rights").

9 See, e.g., James Edwards, A Patents as Property Rights History Lesson, IPWATChDOG (Sept. 7, 2017), http://www.ipwatchdog.com/2017/09/07/patents-property-rights-history-lesson/id=87644/ ("[T]hat a patent is private property affording the owner private property rights should be without question" due to "two centuries' worth of statutes and judicial rulings and patterns and practice operationalizing private property rights in patents.").

${ }^{10}$ See, e.g., Brief for Amici Curiae Abbvie, Inc. et al. in Support of Petitioner at 3, Oil States Energy Servs., LLC v. Greene's Energy Group, (U.S. argued Nov. 27, 2017) (No. 16-712), 2017 WL 3888200.

${ }^{11}$ Mark A. Lemley, The Surprising Resilience of the Patent System, 95 TEX. L. REV. 1, 1-2 (2017).

${ }^{12} I d$. at $7-8,10-11$.

${ }^{13} I d$. at 3-6.

${ }^{14}$ See id. at 51 (noting that the changes observed in the patent system may not be as dramatic as contended because of the possibility of more radical changes, like a working requirement or exclusion of some technologies from patent protection).
} 
institutional structure, and the basic doctrines of patent law. The foundational and systemic aspects of the patent system that persist today emerged by the middle fifty years of the 19th century (18251875). Thus, the characteristics of our modern patent system reflect less the influence of the Framers or of the 18th century than they do the influence of the early to middle of the 19th century.

After establishing our 19th century patent system in Part I, Part II describes the consequences that our 19th century patent system has for present policy debates over patent law. A brief conclusion follows.

\section{ReCOGNIZING OUR 19Th CENTURY PATENT SySTEM}

Commentators have recognized the 19th century origins of various aspects of the patent system. For example, Professor Michael Burstein noted that "[t]he administrative structure of the modern American patent system was first set forth in the Patent Act of 1836" and "has remained largely unchanged." 15 Professor Adam Mossoff recognized that "[m]uch of modern American patent law comprises doctrines first created by courts in the nineteenth century." 16 And a major argument against the new powers the AIA gave the Patent Office to cancel issued patents is based on historical stability in the nature of patent rights, namely the long-standing principle that a "granted U.S. patent affords its owner a substantial property right" ${ }^{17}$ over which the government has "relatively limited" control. ${ }^{18}$

In fact, the last two comprehensive patent acts before the AIA - the Patent Act of 1870 and the Patent Act of 1952-largely focused on reorganization and codification of judicial developments, without making significant changes. ${ }^{19}$ Development in patent law since the mid19th century thus has occurred through the common law process, naturally leading to incremental development of the doctrinal formulations for implementing law but not foundational or systemic changes that significantly depart from past practice. ${ }^{20}$ This judicial development of patent law helps explain the stability in the foundational aspects of the patent system. The common law process allows flexibility to adjust doctrinal formulations to changing societal, technological, and political needs, thereby relieving pressure that otherwise might provide an impetus for foundational or systemic changes. ${ }^{21}$

This Part provides a comprehensive view of how the foundational and systemic aspects of the American patent system fluctuated significantly in the early years before stabilizing into their present forms in the mid-19th century.

\section{A. $\quad$ The Nature of Patent Rights}

1. General-Applicable Legislation with Uniform Criteria

American patent law is generalized and standardized, normally applying uniform criteria

\footnotetext{
${ }^{15}$ Burstein, supra note 6, at 1761.

${ }^{16}$ Adam Mossoff, Exclusion and Exclusive Use in Patent Law, 22 HARV. J. L. \& TECH. 321, 324 (2009).

${ }^{17}$ Brief as Amicus Curiae Intellectual Property Owners Association in Support of Neither Party at 3, Oil States Energy Servs., LLC, INC. v. Greene's Energy Grp., LLC, (No. 16-712) 2017 WL 3888207.

${ }^{18}$ Brief Amici Curiae AbbVie, Inc. et al. at 14-15, Oil States Energy Servs., LLC, INC. v. Greene's Energy Grp., LLC, (No. 16-712) 2017 WL 3888207.

${ }^{19}$ Craig Allen Nard, Legal Forms and the Common Law of Patents, 90 B.U. L. REV. 51, 70-73 (2010).

${ }^{20} \mathrm{Id}$. at $99-106$ (noting that common law process is better at making incremental changes than significant

${ }^{21}$ Thanks to Chris Beauchamp for suggesting this point to me.
} reforms). 
enacted through general legislation to all inventors and inventions, rather than using special bills or ad hoc criteria. ${ }^{22}$ Though long-standing, this approach was not inevitable.

Initially, it appeared that American patents would follow their English, colonial, and state predecessors as "discretionary ad hoc grants" by the crown or the legislature, issued on a case-bycase basis and differing in their terms, conditions, and duration. ${ }^{23}$ The First Congress received petitions from inventors, assuming an ad hoc approach, for exclusive rights in their inventions. ${ }^{24}$ Both the House and the Senate appointed committees to review these petitions, which in some instances recommended passing special bills to grant exclusive rights to the inventors based on a case-by-case evaluation of the desirability of patent protection. ${ }^{25}$ One special bill—-for exclusive rights to Francis Bailey for a printing press that prevented counterfeiting - even passed the House but only after an individualized evaluation of its usefulness by Secretary of the Treasury Alexander Hamilton. ${ }^{26}$

Congress never enacted these special bills, choosing instead to use general legislation to provide exclusive rights to inventors. ${ }^{27}$ The Patent Act of 1790 adopted an approach of "generalization and standardization": "general substantive criteria of patentability"; "standard, uniform procedures for granting patents"; and "general uniform entitlements to be bestowed by all patents." ${ }^{28}$ Despite this early move towards generalization and standardization, the American patent system retained significant elements of a discretionary, ad hoc approach to patents into the middle of the 19th century.

First, early American patent law departed from generalization and standardization in its treatment of foreign inventors. The Patent Act of 1793 limited patent protection to "citizens of the United States," 29 while the Patent Act of 1800 gave noncitizens the same rights as citizens with regards to patents, but only if they had lived in the United States for two years. ${ }^{30}$ Congress sometimes sidestepped this requirement by granting patent protection to foreign citizens via private bills on a discretionary, ad hoc basis. ${ }^{31}$

The Patent Act of July 13, 1832 extended patent protection to any noncitizen residing in the United States who declared an intention to become a citizen, but departed from the normally standardized approach to patent protection by imposing additional requirements on those who resided for less than two years, namely, that the patent rights shall "become absolutely void without resort to any legal process to annul or cancel the same" if the invention was not publicly used in the United States or if the patentee did not become a citizen. ${ }^{32}$ The Patent Act of 1836 eliminated

${ }^{22}$ Robert Patrick Merges \& Glenn Harlan Reynolds, The Proper Scope of the Copyright and Patent, 37 HARV. J. ON LEGIS. 45, 61-62 (2000) (describing "a tradition of congressional unease with the legislation of private patent bills" that led it to incorporate special requests into generally-applicable legislation).

${ }^{23}$ OREN BRACHA, OWNING IDEAS: THE INTELLECTUAL ORIGINS OF AMERICAN INTELLECTUAL PROPERTY, 17901909, 16-17, 25-26, 31 (Cambridge University Press 2016).

${ }^{24}$ Edward C. WALterscheid, To Promote the Progress OF UsEFUl ARTs: AmERICAN PATENT LAW AND ADMINISTRATION, 1798-1836, 82-83 n.4 (1998).

${ }^{25} \mathrm{Id}$. at 83 (describing House committee report recommending exclusive rights in maps, globes, etc. to inventor of new means of determining longitude); $i d$. at 118-119 (describing Senate committee report recommending exclusive rights for new printing press that prevented counterfeiting).

${ }^{26}$ Id. at 116-117 (describing H.R. 44, which passed the House on March 4, 1790).

${ }^{27} \mathrm{Id}$. at $84,120$.

${ }^{28}$ BRACHA, supra note 23, at 193.

${ }^{29}$ Patent Act of 1790 , ch. $7, \S 1$ Stat. 100.

${ }^{30}$ Patent Act of 1800, ch. 25, § 1 Stat. 37.

${ }^{31}$ Merges \& Reynolds, supra note 22, at 61 \& n.67.

${ }^{32}$ Patent Act of July 13, 1832, ch. 203, Stat. 577. 
this automatic cancellation for nonuse but made it a defense in infringement litigation that a foreign patentee "had failed and neglected for the space of eighteen months from the date of the patent, to put and continue on sale to the public, on reasonable terms" the patented invention. ${ }^{33}$ This last significant remnant of non-standardized and discriminatory treatment of noncitizens was dropped in the Patent Act of $1870 .{ }^{34}$

The second major departure from generalization and standardization in early American patent law was Congress's grants of patent term extensions on a discretionary basis via private bills. ${ }^{35}$ Over the first half of the 19th century, there was an "evolution of ad hoc legislation into a system of regularized procedures subject to judicial review." 36 The Patent Act of July 3, 1832 provided a procedure by which to seek term extensions from Congress, though without imposing any standardized criteria for granting extensions. ${ }^{37}$ The Patent Act of 1836 made this even more standardized by providing a procedure for obtaining an extension through the Patent Office based on specific criteria, namely, that the inventor failed to obtain "a reasonable remuneration for the time, ingenuity, and expense" of inventing and commercializing the invention (as shown by specific evidence of costs and profits). ${ }^{38}$ Amendments to the patent statutes in 1861 abolished patent term extensions, offering a single term of 17 years for all patents. ${ }^{39}$ Private bills for patent term extensions continued to be sought from Congress but were apparently rarely granted and the practice died out towards the end of the 19 th century. ${ }^{40}$

\section{Strong Exclusionary Property Interest}

An issued patent today creates a strong property interest in the patentee, providing a nearabsolute right to exclude others from making, using, or selling the disclosed invention, without policy-based third-party use rights or compulsory licensing. ${ }^{41}$ "[T] $]$ his identification of patents as property itself reflects a long-standing historical treatment of patents in both Congress and the courts," 42 but one that emerged only in the early 19th century.

Pre-Constitution, patents were royal prerogatives or government entitlements, not property rights. ${ }^{43}$ The rights they conveyed varied, they were inalienable and personal to the grantee, and

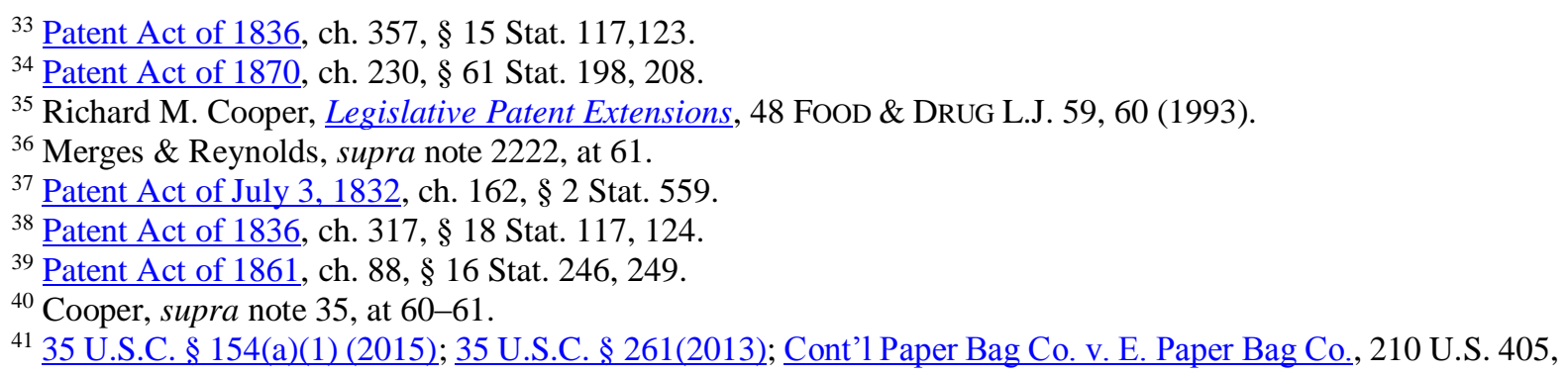
423-424 (1908) (explaining that Congress has long "provide[d] for an exclusive right to inventors to make, use and vend their inventions" with almost "no qualification . . . of the right"). Limited prior user rights defenses have existed on-and-off in American patent law from 1839 until today. See Jeff Mikrut, How the America Invents Act Revived the Prior-User Defense, ABA SECTION OF LITIGATION INTELlECTUAL PROPERTY (Feb. 20, 2012), http://apps.americanbar.org/litigation/committees/intellectual/articles/winter2012-prior-user-defense-americainvents-act.html.

42 Adam Mossoff, Who Cares What Thomas Jefferson Thought About Patents? Reevaluating the Patent Privilege in Historical Context, 92 CoRnell L. REV. 953, 1010 (2007) (emphasis added). Patents originally gave a right to practice the invention, and there is dispute when this morphed into merely a right to exclude. Mossoff, Exclusion, supra note 16 , at 339-347.

${ }^{43}$ WALTERSCHEID, supra note 24, at 9-10. 
they could be revoked at the discretion of the sovereign. ${ }^{44}$ The early petitions to Congress seeking patents via private bills assumed American patents would similarly confer government benefits, not property rights. ${ }^{45}$ The Patent Act of 1790 started the move towards patents as property rights by providing a uniform right to exclude and only allowing revocation within one year of issuance on grounds of fraud or non-novelty. ${ }^{46}$ However, the 1790 Act made no mention of property rights nor the alienability of patent rights (though it did reference the patentee's assignees). ${ }^{47}$ It was the Patent Act of 1793 that first described the patent as providing "an exclusive property in the" invention and permitted the patentee "to assign the title and interest in the said invention, at any time." 48 By the early $19^{\text {th }}$ century, "references to patents as property [we]re omnipresent in nineteenth-century patent law." 49

Relatedly, the strong, near-absolute exclusionary right offered by patents was not inevitable. In fact, the Senate passed an amendment to the bill that became the Patent Act of 1790 providing for a system of compulsory licensing if the inventor did not sell the invention in sufficient quantity or at a reasonable price, but Congress ultimately rejected this amendment out of practical concerns about setting the royalty rate. ${ }^{50}$ By the middle of the 19 th century, patents were viewed as providing strong rights to their owners, as "courts provided patents with expansive procedural guarantees, adopting canons of liberal construction for both patents and the patent statutes" and Congress "adopted expansive substantive patent doctrines jurisprudence." 51 Despite repeated requests, Congress never instituted a system of compulsory licensing of patented inventions. ${ }^{52}$ And although the federal government initially "avoided liability for its use of a patent by relying on sovereign immunity," by the late 19th century, several mechanisms existed to enforce patent rights against the federal government and it was suggested that the patent "confers upon the patentee an exclusive property in the patented invention which cannot be appropriated or used by the government itself, without just compensation." 53

\section{Near-Complete Patent Owner Discretion Over Patent Rights}

The patentee's right to make, use, and sell products that embody the patented invention is subject to the states' general police powers, notwithstanding the federal patent. ${ }^{54}$ However, American patent law historically has left it to the patentee to decide what to do with its patent rights with virtually no qualification. ${ }^{55}$

English, colonial, and state patents normally included a variety of restrictions and regulations on the patentee's rights, such as working requirements that mandated practicing the invention within the territory; regulation of price and quality of the patented invention; and

\footnotetext{
${ }^{44}$ BRACHA, supra note 23 , at 16-18, 26.

${ }^{45} I d$. at 192.

${ }^{46}$ Patent Act of 1790, ch. $7 \S \S 1,4-5$ Stat.100, 111.

${ }^{47}$ See id. $\$ 1$.

${ }^{48}$ Patent Act of 1793 , ch. $11 \S 1$, 4 Stat. 318, 322.

${ }^{49}$ Mossoff, Who Cares, supra note 42, at 992-993.

${ }^{50}$ WALTERSCHEID, supra note 24, at 139-141 \& n. 107.

${ }^{51}$ Mossoff, Who Cares, supra note 42, at 998.

${ }^{52}$ Hartford-Empire Co. v. United States, 323 U.S. 386, 417 (1945).

${ }^{53}$ Lionel Marks Lavenue, Patent Infringement Against the United States and Government Contractors Under 28 U.S.C. \$ 1498 in the United States Court of Federal Claims, 2 J. INTELL. Prop. L. 389, 399, 408-411 (1995).

${ }^{54}$ Patterson v. Kentucky, 97 U.S. 501, 506, 507 (1878) (emphasis added).

55 Cont'l Paper Bag Co. v. E. Paper Bag Co., 210 U.S. 405, 423-424 (1908) (emphasis added).
} 
mandatory training of apprentices to practice the invention in the territory. ${ }^{56}$ By contrast, Congress from the beginning did not regulate most patentee's use of their patents. ${ }^{57}$ But, early on, it sometimes exercised its power to do so. Congress for a time regulated foreign citizens' patent rights, ${ }^{58}$ requiring in the Patent Act of 1832 that foreigners introduce their invention in the United States and become citizens to retain their patent protection ${ }^{59}$ and providing a defense to infringement based on the foreign patentee's non-use of the invention in the Patent Act of $1836 .{ }^{60}$ The regulation of foreign patentees' use of their patents ended with the Patent Act of $1870 .{ }^{61}$

\section{B. The Institutional Structure of the Patent System}

\section{The Dominance of Federal Law and Federal Courts}

Federal law and federal courts have been the dominant force in patent law for so long that it would be easy to assume it has always been this way. ${ }^{62}$ Indeed, some recent reform efforts have been questioned exactly because they depart from federal law and federal court dominance of patent law. ${ }^{63}$ But in three significant ways, viable alternatives existed to the dominance of federal law and federal courts until the early to mid-nineteenth century.

First, in the early years of the American patent system, parallel state patent systems were thought permissible and even existed to some extent. ${ }^{64}$ Several states granted their own patents in the years after the Patent Act of 1790 created the federal patent system. ${ }^{65}$ Concurrent state patent power was endorsed by some courts and leading commentators in the early 19th century but never explicitly addressed by the Supreme Court. ${ }^{66}$ For unclear reasons, state patents disappeared at the start of the 19th century, with what seems to be the last state patent granted in 1798 and extended several times in the early $1800 \mathrm{~s} .{ }^{67}$

Second, patent litigation has long been assigned exclusively to federal courts, a notable exception to the general presumption that state and federal courts have concurrent jurisdiction over matters of federal law. ${ }^{68}$ By contrast, under the Patent Act of 1790, state courts apparently had exclusive jurisdiction over patent infringement cases, as the 1790 Act did not specify federal jurisdiction and there was no general federal question jurisdiction at the time. ${ }^{69}$ The Patent Act of 1793 explicitly provided for concurrent state and federal court jurisdiction. ${ }^{70}$ Although not entirely

${ }^{56}$ BRACHA, supra note 23, at 26; id. at 18-19.

${ }^{57}$ Cont'l Paper Bag Co., 210 U.S. at 425, 429.

${ }^{58}$ See id. at 429.

${ }^{59}$ Patent Act of July 13, 1832, 4 Stat. 577 (repealed 1836).

${ }^{60}$ Patent Act of 1836, ch. 357, 5 Stat. 117, § 15.

${ }^{61}$ Patent Act of 1870 , ch. 230, 16 Stat. 198, § 61.

62 See Paul R. Gugliuzza, Patent Law Federalism, 2011 Wisc. L. ReV. 11, 12 (describing "the federal government's absolute authority over the patent system").

${ }^{63}$ See id. at 12-13 (describing debate and concerns about increased state involvement in patent law).

${ }^{64}$ See generally Camilla A. Hrdy, State Patent Laws in the Age of Laissez-Faire, 28 BERKELEY TeCH. L.J. 45

(2013) (discussing presence and acceptance of state patents in the early American patent system).

${ }^{65} \mathrm{Id}$. at 76-77.

${ }^{66}$ Id. at 81-93 (describing endorsement of concurrent state patent powers by New York's highest court and Justice Story in his commentaries).

${ }^{67} I d$. at 76-80.

${ }^{68}$ Gugliuzza, supra note 62 , at $12,17$.

${ }^{69}$ Donald Shelby Chisum, The Allocation of Jurisdiction between State and Federal Courts in Patent Litigation, 46 WASH. L. REV. 633, 635-636 (1971).

${ }^{70} \mathrm{Id}$. at 636. 
clear and subject to some debate, revisions to the patent statutes in 1800 seemed to make federal jurisdiction exclusive. ${ }^{71}$ Thus, after significant early variation, "it became the established rule in 1800 , maintained to this day, that federal jurisdiction over infringement actions is exclusive of the state courts." 72

Third, beyond simply resolving patent disputes, federal courts long have been the dominant actor in developing patent law and policy. ${ }^{73}$ Congress was actively involved in shaping patent law in the early years, engaging in three substantial restructurings of patent law in the first half century of the patent system. ${ }^{74}$ Subsequently, however, "[t]he history of substantive legislative action in patent law is . . largely one of obeisance," with "congressional action . . . be[ing] an exercise in codification of judicial pronouncements or a locking-in of innovations emanating from the patent bar and other interested stakeholders."75 Moreover, the Patent Office is a comparatively weak administrative agency, traditionally only charged with the comparatively routine task of factspecific evaluations of patent applications for compliance with the criteria of patentability and with little role in making policy decisions or developing the substantive legal criteria for patent protection. ${ }^{76}$ Thus, federal judges have long been "the principal architects" and "traditional policy driver[s]" of the patent system. ${ }^{77}$

Indeed, the most significant changes to the institutional structure of the patent system from the 19th century until recently occurred solely within the federal courts. Appellate review of both patent examination and patent litigation has shifted among various federal courts over the years, most notably with the centralization of all patent appeals in the United States Court of Appeals for the Federal Circuit in the early 1980s. ${ }^{78}$ Additionally, there have been multiple swings in the degree to which juries have been involved in patent cases over the years. ${ }^{79}$ In contrast to these changes within the federal courts, the relationship of federal courts to other institutional actors remained largely stable from the early to mid-19th century until recently.

\section{Pre-Issuance Examination}

The Patent Office's substantive, pre-issuance examination of patent applications for compliance with the statutory criteria of patentability so familiar today ${ }^{80}$ only emerged after an initial period of significant instability in the institutional structure of the patent system.

Traditionally, patents had been granted in England, the colonies, and the states by petition to the sovereign or legislature, which evaluated the petition to determine whether to issue a patent. ${ }^{81}$ By contrast, the earliest proposed American patent legislation would have created a registration system for patents similar to that then-developing in England. ${ }^{82}$ Under this approach,

${ }^{71}$ Id. at 636-637; see also Gugliuzza, supra note 62, at 18-19 (describing the uncertainty in this conclusion); Edward H. Cooper, State Law of Patent Exploitation, 56 MinN. L. REV. 313, 317-318 \& nn.13-19 (1972).

${ }^{72}$ Chisum, supra note 69, at 637.

${ }^{73}$ Nard, supra note 19, at 53-55.

${ }^{74} I d$. at $64-70$.

${ }^{75} \mathrm{Id}$. at 53-54.

${ }^{76}$ Burstein, supra note 6, at 1755, 1757.

${ }^{77}$ Nard, supra note 19, at 54-55.

${ }^{78}$ See Mark D. Janis, Patent Law in the Age of the Invisible Supreme Court, 2001 UnIV. OF ILL. L. REv. 387, 389393 (describing some of these appellate variations).

${ }^{79}$ Christopher Beauchamp, The First Patent Litigation Explosion, 125 YALE L.J. 848, $912-913$ (2016).

${ }^{80}$ Burstein, supra note 6, at 1755-56.

${ }^{81}$ BRACHA, supra note 23 , at 17, 27-28.

${ }^{82} I d$. at 22 (describing developing registration system in England). 
the inventor filed a petition describing the invention and provided notice of the invention in newspapers, and if no one objected within a specified time, the patent would issue, examined only for compliance with formalities rather than substantive issues. ${ }^{83}$ But the Patent Act of 1790 ultimately provided for a three-member board of the Secretary of State, Secretary of War, and Attorney General to evaluate patent applications. ${ }^{84}$

The significant demands this system imposed on high-ranking officials led the Patent Act of 1793 to abandon the examination system in favor of "a pro forma process dependent only on completion of the required ministerial acts by the petitioner for the patent." ${ }^{85}$ Omitting the notice and opportunity to object provisions previously proposed, the 1793 Act left all patentability questions to the courts, either in resolving defenses to infringement suits or resolving direct actions to cancel a patent that could be brought within three years of issuance. ${ }^{86}$

Facing concerns about an over-proliferation of weak patents, Congress again altered the process for obtaining a patent in the Patent Act of 1836, creating "the examination system that has remained a fundamental part of the patent law to this day." ${ }^{87}$ Beginning in 1836 and continuing to this day, an inventor desiring patent protection must file an application with the Patent Office, an administrative agency staffed with civil servant examiners charged with reviewing patent applications for compliance with the statutory requirements. ${ }^{88}$ If the application is denied by the examiner, the applicant can appeal within the Patent Office. ${ }^{89}$ The applicant has the additional options of taking a direct appeal to federal court or filing a separate lawsuit in federal court. ${ }^{90}$

\section{Patents as of Right}

A patent applicant has a statutory right to receive a patent upon satisfaction of statutory criteria that are directed exclusively to technical considerations: novelty and non-obviousness, eligible subject matter and utility, and adequate disclosure. ${ }^{91}$ The Patent Office has no discretion to weigh policy or economic considerations or weigh costs and benefits of individual patents to grant a patent where the technical criteria are not satisfied or deny protection where they are. ${ }^{92}$ This fundamental aspect of the modern patent system was an innovation of the early American patent system.

No right to a patent existed in the pre-Constitution English, colonial, or state practice, and patents were instead issued at the discretion of the sovereign. ${ }^{93}$ The 1790 Act did not create any greater right to a patent than under the pre-Constitutional practice, stating only that "it shall and may be lawful" for the patent board to issue a patent without requiring it to do so. ${ }^{94}$ It expressly

${ }^{83}$ WALTERSCHEID, supra note 24 , at 92, 97-98, 135-36.

${ }^{84}$ Id. at $136-37$.

${ }^{85} I d$. at $223,479-82$.

${ }^{86} \mathrm{Id}$. at $481-82$.

${ }^{87} I d$. at 427.

${ }^{88}$ Compare 35 U.S.C. $\S \S 3(b)(4), 131$ (2002) ("The Director shall cause an examination to be made of the application and the alleged new invention”), with Patent Act of 1836, ch. 357, 5 Stat. 117, §§ 1-2, 6-7 (1836) (“[T]he Commissioner shall make or cause to be made, an examination of the alleged new invention or discovery").

${ }^{89}$ Compare 35 U.S.C. $§ 134$, with Patent Act of 1836 , ch. 357,5 Stat. $117, \S 7$.

${ }^{90}$ Compare 35 U.S.C.A. $\S \S 141,145$ (2012), with Patent Act of 1839, ch. 87, 111 Stat. 353.

${ }^{91}$ Burstein, supra note 6, at 1762-63.

${ }^{92}$ Orin S. Kerr, Rethinking Patent Law in the Administrative State, 42 WM. \& MARY L. REV. 127, 138-40 (2000).

${ }^{93}$ BRACHA, supra note 23, at 190.

${ }^{94}$ Patent Act of 1790, ch. 7, 1 Stat. 109, § 1 (amended 1793); BRACHA, supra note 23, at 193; WALTERSCHEID, supra note 24 , at $168-69$. 
required discretionary, policy-based decision making, permitting patent issuance only if the patent board "deem[ed] the invention or discovery sufficiently useful and important." 95 And no right of appeal, means of review, or remedy was provided for an unsuccessful patent applicant. ${ }^{96}$ The 1790 Act did mark the beginning of the American patent system's road to a statutory right to patent protection by defining standardized criteria for patentability for the patent board to apply, standardized rights granted by a patent, and a standardized process for obtaining a patent. ${ }^{97}$

The Patent Act of 1793 represented a significantly larger step towards a non-discretionary right to a patent. Although it only stated that "it shall and may be lawful" to issue a patent, it was widely understood as mandating patent issuance upon satisfaction of a few formalities, without any government discretion to deny the petition. ${ }^{98}$ Yet, the patent applicant still had no enforceable right to a patent, as the statute omitted any right to appeal, means of review, or remedy if an applicant was denied patent protection. ${ }^{99}$ Additionally, some courts used the 1793 Act's utility requirement to perform the patent board's prior role of evaluating the social value and costs of the invention. ${ }^{100}$

By the end of 1830s, patents took their modern form as a right of anyone who satisfied the statutory criteria, without any discretion or policy-weighing. The Patent Act of 1836 expressly provided that "it shall be [the Commissioner of Patent's] duty to issue a patent therefor" if the examination determined that the invention satisfied the statutory criteria. ${ }^{101}$ Although the 1836 Act maintained language allowing the Commissioner to determine if the invention was "sufficiently useful and important," the Patent Office never treated this language as giving it open-ended discretion to evaluate the social value or costs and benefits of inventions. ${ }^{102}$ The 1836 Act also gave a dissatisfied applicant the opportunity to appeal to a board of disinterested experts, requiring the Commissioner to justify the refusal and giving the board the power to overrule the commissioner. ${ }^{103}$ The Patent Act of 1839 completed the move to patents as non-discretionary rights, allowing the patentee to enforce this right in the courts by either appealing the Commissioner's decision to the federal district court or by filing a bill of equity seeking patent issuance. $^{104}$

\section{The Patent Office's Limited Post-Issuance Role}

For most of the history of the American patent system, the Patent Office had a limited role after patent issuance, with no involvement in enforcement of the patent or re-evaluating the validity of issued patents. ${ }^{105}$ The Patent Office's role has expanded over the past few decades, with Congress first creating reexamination procedures for the Patent Office to review and cancel issued patents and then significantly expanding these powers in the AIA. ${ }^{106}$ This expanded role for the Patent Office is controversial exactly because it departs from the Patent Office's historically

\footnotetext{
95 Patent Act of 1790 , ch. 7, 1 Stat. 109, $\$ 1$ (amended 1793).

96 BRACHA, supra note 23, at 194; WALTERSCHEID, supra note 24, at 170.

${ }^{97}$ BRACHA, supra note 23, at 193.

${ }^{98}$ Id. at 201-02.

99 WALTERSCHEID, supra note 24, at 224.

${ }^{100}$ BRACHA, supra note 23, at 203-06.

${ }^{101}$ Patent Act of 1836 , ch. 357, 5 Stat. 117, $\S 7$.

102 WALTERSCHEID, supra note 24, at 428.

${ }^{103}$ Patent Act of 1836 , ch. 357, 5 Stat. 117, $§ 7$.

${ }^{104}$ Patent Act of 1839 , ch. 87, 111 Stat. 353, §§ 10-11.

105 See McCormick Harvesting Mach. Co. v. C. Aultman \& Co., 169 U.S. 606, 608-609 (1898).

${ }^{106}$ Cuozzo Speed Techs., LLC v. Lee, 136 S. Ct. 2131, 2137, 2144 (2016).
} 
limited post-issuance role. ${ }^{107}$

Traditionally, in England, post-issuance patent issues were, in part, the province of the executive, i.e., the crown, acting through its council of advisors, the Privy Council. Competitors could petition the Privy Council seeking annulment of previously granted patents, while patentees could petition the Privy Council seeking to have infringers tried before the Council for contempt of the royal grant. ${ }^{108}$ Over the course of the 18th century, post-issuance patent issues increasingly shifted to the courts, ${ }^{109}$ and the Privy Council largely abandoned any post-issuance role by the end of the century. ${ }^{110}$

Initially, the American patent system gave the executive no post-issuance role. Under both the Patent Acts of 1790 and 1793, patentees had a private right of action for infringement in the courts, and competitors could ask the courts to cancel issued patents either in defense of an infringement suit or in direct annulment actions in the courts, but the executive branch had no role in the enforcement, review, or regulation of issued patents. ${ }^{111}$ Indeed, for a period, the executive's pre-issuance role had no impact on post-issuance patents. The 1790 Act provided that issuance of the patent constituted prima facie evidence of its validity, ${ }^{112}$ but under the registration system of the 1793 Act, "a patent was not received in courts of justice as even prima facie evidence that the invention patented was new or useful."113

Over the first few decades of the 19th century, the Patent Office took on the limited postissuance role that it held until recently. First, without substantive pre-issuance examination under the 1793 Act, patentees increasingly discovered validity problems post-issuance and returned to the Patent Office seeking to surrender their original patent and receive a replacement amended to address the problem. ${ }^{114}$ The Patent Office began granting such reissue requests in the $1810 \mathrm{~s},{ }^{115}$ and Congress codified it in $1832 .{ }^{116}$ The reissue practice remains essentially the same today, though with several limits on broadening claim scope that the Supreme Court introduced in the late 19 th century. ${ }^{117}$

Second, the Patent Act of 1836 expanded the Patent Office's power to resolve interferences - contests between competing claimants of the same invention to determine who is entitled to the patent - to cover not just interferences between pending applications but also interferences between pending applications and issued patents. ${ }^{118}$ This interference power continued until it was abolished by the AIA, though in 1952, Congress granted the Patent Office the power to directly cancel issued patents that lost in interferences rather than requiring a separate

${ }^{107}$ See, e.g., Brief of J. Kenneth Blackwell et al. as Amici Curiae for Petitioner at 21-25, Oil States Energy Servs., LLC v. Greene's Energy Group, (U.S. argued Nov. 27, 2017) (No. 16-712), 2017 WL 3888200.

${ }^{108}$ Sean Bottomley, Patent Cases in the Court of Chancery, 1714-58, 35 J. Legal HIST. 27, 27-28 (2014).

${ }^{109}$ See generally id.

${ }^{110}$ E. Wyndham Hulme, Privy Council Law and Practice of Letters Patent for Invention From the Restoration to 1794 II, 33 L. Q. Rev. 180, 192-193 (1917) (showing the last cancellations occurring in the 1770s, with additional unacted upon petitions subsequently).

${ }^{111}$ Patent Act of 1790, ch. 7, 1 Stat. 109, §§ 4-6 (amended 1793); Patent Act of 1793, ch. 11, 1 Stat. 318, § 5-6, 10 (repealed 1836).

${ }^{112}$ Patent Act of $1790 \S 6$.

113 Corning v. Burden, 56 U.S. 252, 270 (1853).

${ }^{114}$ WALTERSCHEID, supra note 24 , at 266-267.

${ }^{115} \mathrm{Id}$.

${ }^{116}$ Patent Act of 1832, ch. 162, 4 Stat. 559, § 3 (repealed 1836).

117 DONALD S. Chisum, Chisum On PATENTS $§ 15.02[5]$, [9]-[10] (2018).

${ }^{118}$ Patent Act of 1836, ch. 357, 5 Stat. 117, $\S 8$. 
court action. ${ }^{119}$

Third, even in the decade or two before the return to pre-issuance examination in the 1836 Act, courts began to emphasize that patents should be treated liberally and in favor of their validity. ${ }^{120}$ Under the examination system of the 1836 Act, the Patent Office's actions in granting the patent once again became prima facie evidence of its validity post-issuance with the burden on the defendant in litigation to establish invalidity. ${ }^{121}$ From the antebellum era until today, issued patents have been presumed valid in litigation, with the defendant required to provide clear and convincing evidence of invalidity. ${ }^{122}$

\section{The Substantive Doctrines of Patent Law}

\section{The Statutory Criteria of Patentability}

Despite the traditional absence of uniform standards for patents, the basic statutory criteria of patentability emerged early in the American patent system. ${ }^{123}$ The basic doctrinal framework of patentability has remained the same since the mid-1800s, even as the courts have engaged in common law development to flesh out and implement that framework.

The Patent Act of 1790 included the basic requirements of novelty, utility, and enablement. ${ }^{124}$ "The enablement standard has exhibited markedly little evolution since the days of Justice Story [in the early 1800s]." 125 By the Patent Act of 1836, the novelty requirement had taken the form it would have into the 21 st century: judging novelty as of the date of the invention, requiring that the invention not be previously known or used in the United States or patented or described in a printed publication anywhere in the world, and providing that a patentee lost its right to an invention by publicly using or selling the invention too long before filing the patent application. ${ }^{126}$ And by the time of the Civil War, the utility requirement had evolved into its modern form that requires only a minimal showing of some real-world use rather than the more open-ended evaluation of its social value or importance that had been used in the early 1800 s. $^{127}$

Even the patentability doctrines most controversial in recent years developed, at least in their basic form, by the mid-19th century. The basic statutory categories of eligible subject matter-process, machine, manufacture, or composition of matter-have existed virtually unchanged since the Patent Act of $1793,{ }^{128}$ and the judicially-created exceptions against patenting laws of nature, products of nature, and abstract ideas "have defined the reach of the statute as a matter of statutory stare decisis going back 150 years" to an 1853 decision. ${ }^{129}$ Likewise, the basic

119 P.J. Federico, Commentary on the New Patent Act, 75 J. PAT. \& TRADEMARK SoC. 161, 198 (1993).

${ }^{120}$ Mossoff, Who Cares, supra note 42, at 999.

${ }^{121}$ Corning v. Burden, 56 U.S. 252, 270-71 (1853).

122 Microsoft Corp. v. i4i Ltd. P'ship, 131 S. Ct. 2238, 2245 (2011).

${ }_{123}$ Mossoff, Exclusion, supra note 16, at 324 ("Much of modern American patent law comprises doctrines first created by courts in the nineteenth century. . .").

${ }^{124}$ Nard, supra note 19, at 64.

${ }^{125}$ Mark D. Janis, On Courts Herding Cats: Contending with the "Written Description" Requirement (and Other Unruly Patent Disclosure Doctrines), 2 WASH. U. J.L. \& POL'Y 55, 57 (2000).

${ }^{126}$ WALTERSCHEID, supra note 24, at 378, 391-393, 428-429.

127 BRACHA, supra note 23, at 215-216; id. at 203-208.

${ }^{128}$ Bilski v. Kappos, 130 S. Ct. 3218, 3243, 3247 (2010) (Stevens, J., concurring in the judgment) (noting that the 1793 Act deemed patentable subject matter any new and useful art, machine, manufacture, or composition of matter, and any improvement thereto, and that the replacement of art with process in 1952 was non-substantive).

${ }^{129}$ Id. at 3225. 
requirement that the invention be non-obvious - not just new but significantly different and a nontrivial change to a skilled artisan-originated in an 1851 Supreme Court case, ${ }^{130}$ if not before. ${ }^{131}$ Finally, the Federal Circuit recently explained that "since 1793, the Patent Act has expressly stated that an applicant must provide a written description of the invention, and after the 1836 Act added the requirement for claims, the Supreme Court applied this description requirement separate from enablement." 132

The last patentability requirement to develop was the requirement that the patentee "particularly point[] out and distinctly claim[] the subject matter" of the invention. ${ }^{133}$ Under the 1793 Act, patentees began voluntarily including claims as a distinct component of the specification to distinguish their invention from the prior art, and the 1836 Act codified this procedure to some extent. ${ }^{134}$ In adopting the modern language in 1870, Congress formalized the growing practice of peripheral claiming - precisely claiming the invention to signal the outer bounds of the right - that had replaced the prior practice of central claiming - describing the primary embodiment and then asserting rights to a surrounding zone of equivalents. ${ }^{135}$ American patent law continues to use the peripheral claiming practice adopted in $1870,{ }^{136}$ while " $[\mathrm{t}]$ he 1870 Act's definiteness requirement survives today, largely unaltered." 137

\section{Infringement}

Under modern patent law, liability for infringement requires that the defendant make, use, sell, offer to sell, or import the claimed invention or its equivalent. ${ }^{138}$ Liability for offering to sell and for importing the invention was added in the 1990s as part of harmonization of American patent law with international patent law. ${ }^{139}$ Otherwise, the infringement doctrine remains largely the same as in the mid-1800s.

The 1790 Act gave patentees a claim for infringement against those who "make, construct, use, employ, or vend," while the 1793 Act modified these acts of infringement to "make, devise and use, or sell" and the 1836 Act adopted the acts of "making, using, or selling" that would remain the same until the 1990s. ${ }^{140}$ Through the middle of the century, when central claiming was the dominant approach, determining whether the accused product was infringing involved determining the key features of the invention from the patent as a whole and then determining whether the accused product was close enough to the invention. ${ }^{141}$ But with the formalization of claims in the

${ }^{130}$ Graham v. John Deere Co., 383 U.S. 1, 11-17 (1966) (describing origin of non-obviousness requirement and describing Congress's codification of non-obviousness in 1952 as adopting standard introduced by Court in 1851).

131 WALTERSCHEID, supra note 24, at 385-386 (describing how courts under 1793 Act applied a "substantial novelty" requirement similar to the later-developed non-obviousness requirement).

132 Ariad Pharms., Inc. v. Eli Lilly \& Co., 598 F.3d 1336, 1345-48 (2010)

133 35 U.S.C. $\$ 112$ (2012).

134 Nard, supra note 19 , at 66-67, 70.

135 Id. at 71 .

${ }^{136}$ Dan L. Burk \& Mark A. Lemley, Fence Posts or Sign Posts: Rethinking Patent Claim Construction, 157 U. PA. L. REV. 1743 (2009).

${ }^{137}$ Nautilus, Inc. v. Biosig Instruments, Inc., 134 S. Ct. 2120, 2125 (2014)

${ }^{138}$ Markman v. Westview Instruments, Inc., 517 U.S. 370, 374 (1997).

1391 Donald S. Chisum, Chisum ON PATENTS $\S 16.02[5][\mathrm{g}]$, [8] (2017).

${ }^{140}$ Patent Act of $1790 \S 4$, ch. 7, 1 Stat. 109, 111 (prior to 1793 amendment); Patent Act of $1793 \S 5$, ch. 10,1 Stat. 318, 322 (amended 1836); Patent Act of $1836 \S$ 14, Pub. L. No. 24-357, 5 Stat. 117 (amended 1952).

${ }^{141}$ Burk \& Lemley, supra note 136, at 1746. 
1870 Act and the move to peripheral claiming in the $1870 \mathrm{~s},{ }^{142}$ infringement required a showing that the accused product fell within the language of the claim, as it does today. ${ }^{143}$

To be fair, although peripheral claiming has existed since the $1870 \mathrm{~s}$, the process of interpreting claim language for purposes of infringement and invalidity arguably has changed significantly in the twenty years since the Supreme Court held that claim construction was a matter for the judge, not the jury, in Markman $v$. Westview Instruments. ${ }^{144}$ The past two decades have seen prior practice of treating interpretation of the claims as part of the infringement or invalidity inquiry (and often leaving it to the jury) replaced by so-called Markman hearings, pre-trial proceedings where the judge explicitly defines the claim language. ${ }^{145}$ Markman hearings have become the most important event in patent litigation and may have substantively changed the methodology and outcomes of patent claim interpretation. ${ }^{146}$

Finally, the liability for infringement not just for products that are the same as the claimed invention but also for those that are equivalent developed out of the favorable treatment courts gave patentees in the first half of the 19th century, when they focused on the principle of the invention and asked whether the accused product was substantially the same. ${ }^{147}$ With the rise of claims towards the middle of the century, courts increasingly asked whether the accused product fell within the exact scope of the claims and, if not, whether equitable considerations warranted expanding the scope of the claim to cover the accused product. ${ }^{148}$ The doctrine of equivalents in its modern form is generally traced to an 1853 case. ${ }^{149}$

\section{Remedies}

Precursors to American patents often specified the penalty for infringement, which varied from patent-to-patent, for example, half the value of infringing sales; three times the value of infringing sales; the greater of twenty pounds per infringing product or the value of the infringing product; and replevin of the infringing products. ${ }^{150}$

The Patent Act of 1790 departed from these types of liquidated damages provisions by permitting the patentee to recover generally "such damages as shall be assessed by a jury." 151 The Patent Act of 1793 standardized damages at an amount "that shall be at least equal to three times the price, for which the patentee has usually sold or licensed" the patented invention (modified by the Patent Act of 1800 to be three times the actual damages sustained). ${ }^{152}$ Since the Patent Act of 1836 , the patentee's "actual damages" have been the base measure of what the patentee is entitled to recover. ${ }^{153}$ Measuring damages by the established royalty rate or the patentee's lost profits from

\footnotetext{
${ }^{142}$ See Part I.C.1, supra.

${ }^{143}$ Markman, 517 U.S. at 374; see also id. at 1765-66 (describing development of this approach to judging infringement in 1870s).

144517 U.S. 370.

${ }^{145}$ Burk \& Lemley, supra note 136, at 1750.

${ }^{146} I d$. at $1761,1795$.

${ }^{147}$ Michael J. Meurer \& Craig Allen Nard, Invention, Refinement and Patent Claim Scope: A New Perspective on the Doctrine of Equivalents, 93 GEO. L.J. 1947, 1961-62 (2005).

${ }^{148}$ Id. at 1963.

${ }^{149} I d$. at 1963-67; see Winans v. Denmead, 56 U.S. 330 (1853).

${ }^{150}$ Edward C. Walterscheid, The Early Evolution of the U.S. Patent Law: Antecedents (5, Part II), 78 J. PAT. \& TRADEMARK OFF. SOC'Y 665, 669-72 (1996).

${ }^{151}$ Patent Act of $1790 \S 4$, ch. 7, 1 Stat. 109, 111 (prior to 1793 amendment).

${ }^{152}$ Patent Act of $1793 \S 5$, ch. 10, 1 Stat. 318, 322 (amended 1836); Patent Act of $1800 \S 3$.

${ }^{153}$ Patent Act of $1836 \S 14$, Pub. L. No. 24-357, 5 Stat. 117 (amended 1952).
} 
selling the product emerged in the early 19th century and remain measures of damages today. ${ }^{154}$ The most common measure of damages today - a reasonable royalty - emerged at the end of the 19th century. ${ }^{155}$

Beyond compensatory damages, the judge in an infringement suit has had discretion since the Patent Act of 1836 to award up to three times the actual damages in cases involving willful infringement. ${ }^{156}$ And the Patent Act of 1819 introduced equity jurisdiction in American patent cases, along with the "authority to grant injunctions, according to the course and principles of courts of equity." 157 Subsequently, "[f]rom at least the early 19th century, courts have granted injunctive relief upon a finding of infringement in the vast majority of patent cases."158

\section{Evaluating Our 19Th Century Patent System}

The modern American patent system thus reflects the stabilizing of fundamental and systemic characteristics in the middle of the 19th century, following significant change and diversity in the first fifty years. Turning to the consequences of the descriptive account provided in Part I, this Part suggests that the long-standing foundational and systemic stability may explain why patent law is seemingly impervious to the doctrinal variations that occur but also introduces inconsistencies between patent law and the modern legal world and results in mistaken assumptions that familiar features of the patent system are somehow mandatory and inevitable and therefore beyond the power of Congress to alter.

\section{A. $\quad$ Our 19th Century Patent System \& Patent Stability}

Our 19th century patent system may help explain Professor Mark Lemley's recent observation that "[t] he patent system . . s seems surprisingly resilient to changes in the law," with "the data show [ing] very little evidence that patent owners and challengers are behaving differently because of changes in the law." ${ }^{159}$ Lemley identifies several possible explanations for this resiliency: selection effects, economic trends, irrelevance of the merits to behavior in the patent system, and irrelevance of formal patent law to behavior in the patent system. ${ }^{160}$

Recognizing the 19th century nature of our patent system offers another possible explanation: the patent system has not experienced the "truly dramatic change" that Professor Lemley suggests. ${ }^{161}$ Professor Lemley describes "multiple swings between eras of strong and weak patent protection" 162 that have occurred at the operational level of the specific tests and defenses that govern doctrinal requirements, such as obviousness, exceptions to patent-eligible subject matter, the doctrine of equivalents, calculation of damages, and availability of attorneys' fees. ${ }^{163}$

154 Oskar Liivak, When Nominal is Reasonable: Damages for the Unpracticed Patent, 56 B.C. L. REV. 1031, 1044-46 (2015).

${ }^{155} \mathrm{Id}$. at $1045-55$.

${ }^{156}$ Halo Electronics, Inc. v. Pulse Electronics, Inc., 136 S. Ct. 1923, 1928-30 (2016).

${ }^{157}$ Patent Act of 1819, ch. 19, 3 Stat. 481.

${ }_{158}$ eBay Inc. v. MercExchange, L.L.C., 547 U.S. 388, 395 (2006).

159 Lemley, supra note 11 , at 2.

${ }^{160}$ Id. at 27.

${ }^{161} \mathrm{Id}$. at 1.

${ }^{162} \mathrm{Id}$. at 13 .

${ }^{163} I d$. at 7-8, 10-11. Professor Lemley also mentions the recent reforms to foundational and systemic aspects, like Patent Office post-issuance invalidity proceedings, the switch to a first-to-file system, and the availability of injunctive relief. $I d$. 
The reason that these fluctuations in operational aspects of patent law "don't seem to be enough to change the overall dynamics of the system" 164 may be that they are actually marginal changes to the patent system- "however dramatic the changes in patent doctrine seem to those of us inside the system"165 — when considered in the larger context of the remarkable stability of the patent system's foundational and systemic aspects discussed in Part I.

Professor Lemley recognizes that "[s]ome might contest the claim that the changes we have made to the patent system in the last forty years are as dramatic as I suggest," as I do in this Essay, and envisions that "more radical changes - a working requirement for patents, or excluding software entirely from patent protection" - that is, departures from the long-standing structural and systemic features discussed in Part I - might be "radical enough to bump the patent system out of its established track." 166 Yet, Professor Lemley ultimately rejects stability in the foundational aspects of the patent system as an explanation for the patent system's resiliency, concluding instead that "patent institutions seem to have taken on a life of their own, one largely beyond the reach of the policy levers we employ to try to calibrate innovation incentives." 167

Professor Lemley's conclusion certainly could be right. As he notes, "[w]e haven't tried those things [i.e., changes to the foundational and systemic aspects of the patent system discussed in Part I], so we don't know how the system would react." "168 Moreover, the value to businesses from patents may not come from the formal legal rights, substantive doctrines, and institutional structure that surround them but rather, for example, the signals they provide or the transactions they facilitate. ${ }^{169}$ But this Essay suggests an alternative possibility - that we are not using the right "policy levers" if truly want to calibrate the patent system in a way that will change the balance between innovation incentives and competition in a truly significant way, rather than just at the margins (a question on which this Essay takes no position). Rather, to alter the patent system's basic balance, more focus might need to be given to reforming the foundational and systemic aspects of the patent system, rather than just tweaking substantive patent law at the operational level of doctrinal implementation.

\section{B. $\quad$ Our 19th Century Patent System \& the Modern Legal Landscape}

The 19th century nature of the patent system creates tensions in the modern legal world, resulting in complications in the theoretical justifications, doctrines, rhetoric, and institutional structure of the modern patent system.

Today, "courts and commentators widely agree that the basic purpose of patent law is utilitarian," rather than moral right, reward, or distributive justice: "[w]e grant patents in order to promote innovation, and so we should grant patents only to the extent necessary to encourage such innovation." 170 By contrast, for most of the 19th century, patent theory included concerns of fairness - giving inventors exclusive rights as a reward for their labor and preventing competitors from unjustly enriching themselves by using an invention without paying for it. ${ }^{171}$ These fairness concerns reflected "an era dominated by the labor theory of property and the social contract

${ }^{164} I d$. at 49.

${ }^{165} \mathrm{Id}$.

${ }^{166} I d$. at 51.

${ }^{167} I d$.

${ }^{168} I d$.

${ }^{169}$ Id. at $53-54$.

${ }^{170}$ Dan L. Burk \& Mark A. Lemley, Policy Levers in Patent Law, 89 VA. L. Rev. 1575, 1597-99 (2003).

${ }^{171}$ Meurer \& Nard, supra note 147, at 1956-59. 
doctrine of natural rights philosophy." 172 From this perspective, patents were seen as securing the property right that inventors gained in their invention through their mental labor. ${ }^{173}$ Thus, "much of the early evolution of American patent law resulted from patents being treated as a civil right within the then-dominant political and constitutional context of natural rights philosophy." 174

The continued stability of the foundational and systemic aspects of the patent system despite this changing theoretical justification has important consequences for modern patent law. First, aspects of the patent system that developed in the 19th century based on fairness or natural law-type principles remain today, proving problematic and controversial under modern utilitarian justifications for patent law. Professors Meurer and Nard recognized this problem with regards to the doctrine of equivalents, which developed based on fairness concerns and has proven problematic and theoretically unmoored in the modern patent system. ${ }^{175}$

Second, despite the well-established utilitarian basis for the modern patent system, the rhetoric of fairness, reward, and natural law still influence patent law debates, with those making such arguments often relying on cases from the first half or so of the 19th century to support their contentions. ${ }^{176}$ Indeed, the deep divide among patent stakeholders about whether patent cancellation is a public right that constitutionally can be assigned to an administrative agency, as the AIA's new post-issuance review proceedings do, or a private right that is more properly resolved by Article III courts is at least partially due to the disconnect between our 19th century patent system and the modern legal world. Those defending AIA post-issuance proceedings emphasize the modern, utilitarian concept of patents, arguing, for example, that because "[i]nventors are entitled to patents only for inventions that further the public interest," these proceedings serve "important public purposes ... namely the protection of the public from private monopolies that exceed the bounds authorized by Congress." 177 Those opposed to the AIA proceedings emphasize conceptions from the 19th century of rewarding and protecting the inventor by making issued patents the exclusive property of the patent owner beyond the government's control or the Patent Office's purview. ${ }^{178}$

Third, patent protection is a government intervention into the economy that restricts the normal operation of the free market. ${ }^{179}$ Yet, the foundational and systemic aspects of the patent system developed in the 19th century before extensive administrative regulation and have remained essentially the same despite the development of the modern regulatory state. ${ }^{180}$ The

${ }^{172}$ Mossoff, Who Cares, supra note 42, at 1012.

${ }^{173} \mathrm{Id}$. at $982-83$.

${ }^{174}$ Id. at 1008.

175 Meurer \& Nard, supra note 147.

${ }^{176}$ Brief for Biotechnology Innovation Org. (BIO) et al. as Amici Curiae Supporting Petitioner 8-10, Oil States Energy Servs., LLC v. Greene's Energy Group, (U.S. argued Nov. 27, 2017) (No. 16-712), 2017 WL 3888200. ("Under the patent system created by the Framers, the foundation of a patent right is the inventor's sweat and ingenuity. The Government's obligation is to safeguard and perfect pre-existing inchoate property rights earned by the inventor's own efforts ..." (citing early $19^{\text {th }}$ century cases)).

${ }^{177}$ Brief for Federal Respondent 19-20, Oil States.

178 Brief for Petitioner 18-19, Oil States.

179 See Shubha Ghosh, Patents and the Regulatory State: Rethinking the Patent Bargain Metaphor after Eldred, 19 BERKELEY TECH. L.J. 1315, 1368 (2004) ("The current debate within patent law is largely a debate over the proper role of the state in regulating the marketplace.").

${ }^{180}$ See Orin Kerr, The Case for Patent Law and Criminal Law Exceptionalism in the Administrative State, THE VOLOHK CONSPIRACY (Feb. 12, 2016), https://www.washingtonpost.com/news/volokhconspiracy/wp/2016/02/12/the-case-for-patent-law-and-criminal-law-exceptionalism-in-the-administrativestate/?utm_term=.b38ab2ee7e33. 
patent system therefore does not operate on modern concepts of administrative regulation but rather through the private law mechanisms of contract, property, and tort that dominated in the 19th century. ${ }^{181}$ This creates a disconnect between patent law and the modern administrative state. The patent system does not function based on a broad delegation of power to the Patent Office to use its expertise to develop optimal standards, but rather requires the Patent Office to simply apply the standards developed primarily by courts to specific patent applications. ${ }^{182}$ Because Congress has not traditionally provided substantive rulemaking authority to the Patent Office, its determinations of questions of patent law have not received the deference typical for modern administrative agencies. ${ }^{183}$ And until the Supreme Court resolved the question in 1999, there was debate about whether the Patent Office was even subject to the Administrative Procedures Act that governs the rest of the modern administrative state. ${ }^{184}$

\section{Our 19th Century Patent System \& Patent Change}

The core normative question that arises from recognizing the 19th century nature of our patent system - and is at the center of many of the debates over recent reforms or proposed reforms to the patent system - is whether the patent system should be updated to reflect the modern economy and modern legal world ${ }^{185}$ or should retain its 19 th-century characteristics, even if now exceptional as compared to other areas of law. ${ }^{186}$ A normative conclusion on this question is beyond the scope of this Essay and may vary for different aspects of the patent system. But recognizing that the roots of our patent system lie in the 19th century can provide useful insights into on-going debates about whether, and to what extent, long-standing foundational aspects of the patent system should be altered.

That so much of the patent system has been stable for so long is certainly a relevant consideration that weighs against fundamental changes to the patent system. After all, "a page of history is worth a volume of logic." 187 That Congress has consistently "continued [a] policy through many years" allows us to "assume that experience has demonstrated its wisdom and beneficial effect upon the arts and sciences." 188 This is particularly true because of the need to "be cautious before adopting changes that disrupt the settled expectations of the inventing community." 189 Thus, changes to the fundamental and systemic aspects of the patent system that have remained stable since the mid-1800s should not be undertaken lightly. ${ }^{190}$

Yet, opponents of reform go too far in suggesting that the fundamental and systemic aspects developed in the 19th century are inevitable, necessary, or mandated by the Constitution or Framers. For example, a patent owners' group argued that the AIA post-issuance review

${ }^{181}$ Kerr, Rethinking, supra note 92, at 129-130.

182 Burstein, supra note 6, at 1754-55.

183 See Melissa F. Wasserman, The Changing Guard of Patent Law: Chevron Deference for the PTO, 54 WM. \& MARY L. REV. 1959, 1973-74 (2013).

${ }^{184}$ Dickinson v. Zurko, 527 U.S. 150 (1999).

${ }^{185}$ Ghosh, supra note 179, at 1317 ("I propose that patent law should be viewed as a form of regulation integrated into other activities of the modern regulatory state.").

186 See Kerr, Case, supra note 180 (arguing for patent law exceptionalism because of pre-administrative state origins).

${ }^{187}$ New York Trust Co. v. Eisner, 256 U.S. 345, 349 (1921) (Holmes, J.).

${ }^{188}$ Cont'l Paper Bag Co. v. E. Paper Bag Co., 210 U.S. 405, 429-430 (1908).

${ }^{189}$ Festo Corp. v. Shoketsu Kinzoku Kogyo Kabushiki Co., 535 U.S. 722, 739 (2002).

190 See Lemley, supra note 11, at 55 (cautioning that too significant of changes to the patent system may undermine its resiliency and create a new, less desirable equilibrium). 
proceedings "violate[] precedent and common law traditions mandating that patent owners' property rights be protected by courts of law and juries." 191 It described a modern, regulatory approach to patents as a "meager conception of patent rights [that] contravenes centuries of English jurisprudential tradition, which guards patents as one of the fundamentally most important forms of private property ..."192 Other stakeholders argued that "[a] granted patent necessarily carries with it a judicially-enforceable right to exclude others from the use of a claimed invention." 193 And a group of pharmaceutical companies contended that "the role envisioned [by the Framers] for Congress with respect to patents was relatively limited." 194 On a similar view, an industry organization suggested that Congress could not enact compulsory licensing or "restrict the transfer or licensing of patents" because "[p]atents have traditionally been afforded the same constitutional protections as other private property." 195

These arguments mistake the long-standing, stable characteristics of the patent system as mandatory features of the patent system and treat the 19th century approach to patents as the only legitimate approach. In doing so, they overlook the significant changes and the diversity of approaches in the first fifty years of the patent system. Many of the proposed departures from the 19th century patent system that circulate in patent debates today have historical antecedents in the first fifty years of the patent system, including: executive discretion in issuing patents; greater consideration of whether particular patents are economically and socially warranted; tailored, nonstandardized patent law; treating patents as entitlements or benefits, not property rights; termination of patent rights without court involvement; the absence of injunctive relief; working requirements; regulations on price or other uses of the patented invention; and compulsory licensing.

None of this is to suggest that adopting any of these particular reforms - or even departing from the 19th century characteristics of the patent system generally-is advisable. Again, that question is beyond the scope of this Essay. Rather, while the long-standing stability in the patent system dating to the middle of the 19th century counsels caution in making fundamental reforms to the patent system, the instability and diversity of approaches in the first fifty years of the patent system demonstrate that our 19th century patent system is neither inevitable nor mandatory.

\section{CONCLUSION}

One's view of the patent system depends on what perspective is taken. A narrow focus on the operational level of doctrinal implementation of patent law reveals significant instability and fluctuation in the patent system. A broader focus on the foundational and systemic characteristics of the patent system reveals such substantial stability for so long that the American patent system reasonably can be described as a 19th century patent system. And an even broader focus on the entire history of the American patent system reveals that this stability was only achieved after a period of significant change, diversity, and experimentation in the first few decades of the patent system. The result is a patent system disconnected in significant ways from the modern legal system but one that could be justified on the basis of stability, resilience, and the assumed wisdom

${ }^{191}$ Brief of Amici Curiae Gary Lauder et al. Supporting Petitioner at 4, Oil States Energy Servs., LLC v. Greene's Energy Group, (U.S. argued Nov. 27, 2017) (No. 16-712), 2017 WL 3888200.

${ }^{192} I d$. at 2.

${ }^{193}$ Brief Of 3M Co. et al. as Amici Curiae in Support of Neither Party at 2-3, Oil States Energy Servs., LLC v. Greene's Energy Group, (U.S. argued Nov. 27, 2017) (No. 16-712), 2017 WL 3888200.

${ }^{194}$ AbbVie Oil States Brief, supra note 18, at 14-15.

${ }^{195}$ IPO Oil States Brief, supra note 17, at 3. 
of long-standing practice. At the same time, however, mistaking this long-standing practice and potential policy desirability for necessary, inherent, or mandatory features overlooks the instability, change, and diversity in the early decades of the American patent system. 